Available online at https://jurnal.stmikroyal.ac.id/index.php/jurdimas

\title{
PELATIHAN INSTAGRAM MARKETING UNTUK TENANT INKUBATOR BISNIS TRILOGI
}

\author{
M. Lahandi Baskoro", Maulidian \\ Desain Komunikasi Visual, Universitas Trilogi \\ Agribisnis, Universitas Trilogi \\ email: lahandi@trilogi.ac.id
}

\begin{abstract}
In 2018, the number of Instagram users in Indonesia has reached 55 million users. A year earlier, Jakarta is the champ on Instagram as the most photographed place, surpassing Sao Paulo, New York and Madrid. This phenomenon shows that Instagram is a social network that is trending in Indonesia right now. Trilogi Business Incubator (Inbistro) is a business incubator belonging to the Universitas Trilogi. From observations and discussions, there are still many tenants which assisted by Inbistro who do not understand digital marketing, especially with Instagram. Albeit, Instagram has become a popular social media in Indonesia, including for product promotion. This community service activity will try to answer the problem: how to increase the capacity of Inbistro tenants so that they understand the basics of Instagram marketing? Our training was designed in 3 (three) sessions which discussed: (1) the importance of using Instagram as a marketing tool for a business; (2) How to find quality, free royalty photos and videos for Instagram content; (3) How to find products and sell them on Instagram.
\end{abstract}

Keywords: Instagram marketing, Trilogi Business Incubator, Inbistro, social media, online marketing

\begin{abstract}
Abstrak: Di tahun 2018, jumlah pengguna Instagram Indonesia telah mencapai 55 juta pengguna. Setahun sebelumnya, Jakarta menjadi juara di Instagram sebagai tempat yang paling banyak difoto, melewati Sao Paulo, New York dan Madrid. Fenomena ini menunjukkan bahwa Instagram adalah jejaring sosial yang sedang diminati di Indonesia saat ini. Inkubator Bisnis Trilogi (Inbistro) adalah inkubator bisnis milik Universitas Trilogi. Dari pengamatan dan diskusi, terlihat bahwa masih banyak tenant binaan Inbistro yang belum memahami tentang digital marketing, terlebih dengan Instagram. Padahal Instagram telah menjadi media sosial yang cukup populer di Indonesia, termasuk untuk promosi produk. Kegiatan pengabdian masyarakat ini akan mencoba menjawab permasalahan: bagaimana cara meningkatkan kapasitas tenant Inbistro agar mereka memahami dasar-dasar pemasaran melalui Instagram (Instagram marketing)? Pelatihan kami rancang dalam 3 (tiga) sesi yang membahas: (1) Pentingnya memanfaatkan Instagram sebagai sarana pemasaran suatu bisnis; (2) Cara mencari foto dan video berkualitas, tanpa berbayar, untuk konten Instagram; (3) Cara mencari produk dan menjualnya di Instagram.
\end{abstract}

Kata Kunci: Instagram Marketing, Inkubator Bisnis Trilogi, Inbistro, media sosial, pemasaran daring 
Jurdimas (Jurnal Pengabdian Kepada Masyarakat) Royal

Vol. 2 No. 1, Jan 2019, hlm. 19 - 26

ISSN 2614-7912 (Print)

DOI: https://doi.org/10.33330/jurdimas.v2i1.315

ISSN 2622-3813 (Online)

Available online at https://jurnal.stmikroyal.ac.id/index.php/jurdimas

\section{PENDAHULUAN}

\section{Lansekap Internet Indonesia}

Masyarakat Indonesia kian hari kian terkoneksi dengan internet. Data dari Asosiasi Penyelenggara Jasa Internet Indonesia, dari lebih 262 juta orang penduduk, 143,26 juta jiwa telah mengakses internet (APJII, 2018). Artinya lebih dari $54 \%$ penduduk Indonesia sudah pernah merasakan tersambung dengan dunia online. Lebih lanjut, disebutkan bahwa $65,98 \%$ penguna internet Indonesia, mengakses internet setiap hari dan 26,48\%-nya memanfaatkan internet lebih dari 7 jam perhari. We Are Social juga memperkuat temuan tersebut dengan menyebutkan bahwa rata-rata pengguna internet Indonesia online selama 8 jam 51 menit (2018). Bagi sebagian besar netizen Indonesia, penggunaan media sosial sudah menjadi keseharian rutin. Layanan seperti Youtube, Facebook, Whatsapp dan Instagram adalah empat layanan internet yang paling diminati oleh orang Indonesia (We Are Social, 2018). Selain untuk berbagi informasi dan aktualisasi diri, tak jarang Instagram digunakan sebagai tempat promosi produk. Sebagian penggunanya bahkan memanfaatkan tempat transaksi jual beli. Data dari We Are Social menyatakan bahwa sudah $40 \%$ dari netizen Indonesia sudah pernah melakukan transaksi belanja online (e-commerce), di berbagai platform, tak hanya jejaring media sosial saja.

\section{Instagram dan Promosi}

Instagram saat ini sedang populer di Indonesia. Melansir data yang ditulis oleh Katadata.co.id, mereka menyebutkan bahwa jumlah pengguna Instagram Indonesia telah mencapai 55 juta pengguna (2018). Pada bulan Agustus tahun lalu, Jakarta menjadi juara di Instagram sebagai tempat yang paling banyak difoto, melewati Sao Paulo, New York dan Madrid (CNN, 2017).

Data-data tersebut memberikan gambaran bahwa Instagram kini jadi platform yang digunakan oleh banyak orang Indonesia. Melihat ini artinya ada peluang besar untuk memanfaatkan Instagram sebagai sarana promosi produk. Mengutip dari laman Instagram sendiri, mereka memfasilitasi cara pemasaran digital yang resmi melalui platform-nya: (1) Iklan Foto; (2) Iklan Video; (3) Iklan Carousel; (4) Iklan Cerita. Kami juga melihat bahwa banyak kegiatan promosi produk di Instagram yang memanfaatkan posting berbayar dari akun-akun yang memiliki jumlah follower yang relatif banyak (akun buzzer dan selebriti).

\section{Universitas Trilogi dan Inbistro}

Universitas Trilogi adalah perguruan tinggi di Jakarta Selatan yang memiliki slogan teknopreneur, kolaborasi dan kemandirian. Universitas ini memiliki inkubator bisnis yang populer disebut sebagai Inbistro (inkubator Bisnis Trilogi). Inbistro bertujuan untuk mengembangkan bisnis para tenant binaannya. Hingga tahun lalu, Inbistro setidaknya telah berhasil menyalurkan pendanaan lebih dari 2,9 milyar rupiah (Tech in Asia, 2017) kepada startup yang diasuhnya.

Saat tulisan ini dibuat, Inbistro melakukan inkubasi untuk 14 (empat belas) tenant pendanaan PPK (Program Pengembangan Kewira- 
Jurdimas (Jurnal Pengabdian Kepada Masyarakat) Royal

Vol. II No. 1, Jan 2019, hlm. 19 - 26

ISSN 2614-7912 (Print)

DOI: https://doi.org/10.33330/jurdimas.v2i1.101

ISSN 2622-3813 (Online)

Available online at https://jurnal.stmikroyal.ac.id/index.php/jurdimas

usahaan), 1 (satu) tenant dari skema PPBT (Perusahaan Pemula Berbasis Teknologi), serta 1 tenant dari skema CPPBT (Calon Perusahaan Pemula Berbasis Teknologi). Dari pengamatan dan diskusi, terlihat bahwa masih banyak tenant binaan Inbistro yang belum memahami tentang digital marketing, terlebih dengan Instagram. Padahal Instagram telah menjadi media sosial yang cukup populer di Indonesia, termasuk untuk promosi produk.

\section{Permasalahan dan Target Luaran}

Bagi tenant Inbistro, mereka memiliki kebutuhan untuk menjangkau target pelanggannya dengan memantaatkan beragam media, salah satunya Instagram. Oleh karenanya, usulan pengabdian ini akan mencoba menjawab permasalahan: Bagaimana cara melatih tenant Inbistro agar mereka memahami dasar-dasar pemasaran melalui Instagram?

Menjawab pertanyaan tersebut, maka tujuan dari diadakannya pelatihan ini adalah: Melatih tenant Inbistro agar mereka memahami dasar-dasar pemasaran melalui Instagram. Target luaran dari kegiatan pelatihan ini adalah: (1) kegiatan pelatihan; (2) publikasi di jurnal; (3) video tutorial pelatihan yang diunggah di Youtube

\section{METODE}

Pelaksanaan pengabdian secara garis besar akan dilakukan dalam alur sebagai berikut:

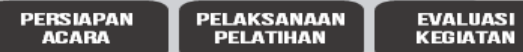

Gambar 1. Alur Pelaksanaan Pelatihan

\section{Persiapan Acara}

Di tahap ini acara pelatihan dikonsepkan apa luaran yang ingin dicapai oleh para pesertanya. Konsep ini lalu didiskusikan internal kami dan dengan narasumber yang akan memberikan pelatihan Instagram Marketing. Pemateri juga perlu untuk membuat materi dan mengkomunikasikan segala sesuatunya jika dibutuhkan untuk peralatan selama pelatihan. Tim pengabdian berkomunikasi dengan Inbistro dan mempersiapkan kepanitiaan. Setelah tanggal ditetapkan, akan dilakukan pengumuman acara ini kepada tenant Inbistro.

\section{Pelaksanaan Pelatihan}

Pemateri dihadirkan dan acara pelatihan dilaksanakan. Penjelasan diusahakan dibagi menjadi beberapa bagian seperti yang sudah disampaikan sebelumnya. Panitia memastikan segala kebutuhan acara telah disiapkan sebelumnya baik konsumsi maupun aspek teknis.

\section{Evaluasi Kegiatan}

Proses ini dilakukan setelah pelatihan dilaksanakan yang bertujuan untuk menganalisis hal-hal positif dan hal-hal yang seharusnya bisa diperbaiki di kesempatan lain. Luaran dari tahap ini adalah rekomendasi.

\section{PEMBAHASAN}

\section{Persiapan Acara}

Kami telah melakukan rapat dengan pihak Inbistro pada 16 November 2018 untuk membahas teknis persiapan kegiatan pelatihan ini. 
Jurdimas (Jurnal Pengabdian Kepada Masyarakat) Royal

Vol. II No. 1, Jan 2019, hlm. 19 - 26

ISSN 2614-7912 (Print)

DOI: https://doi.org/10.33330/jurdimas.v2i1.101

ISSN 2622-3813 (Online)

Available online at https://jurnal.stmikroyal.ac.id/index.php/jurdimas

Pada tanggal 19 November 2018, kami juga telah melakukan diskusi mengenai materi yang direncanakan disampaikan. Pada tanggal 21 November 2018 kami sudah menyebarkan pengumuman kepada tenant Inbistro bahwa pelatihan Instagram Marketing akan diadakan pada tanggal 13 Desember 2018, bagi tenant yang tertarik dan memiliki keluangan waktu dipersilahkan mengisi formulir online yang kami sediakan.

\section{Pelaksanaan Pelatihan}

Acara pelatihan diadakan pada 13 Desember 2018 yang berisi 3 (tiga) materi dari 3 (tiga) narasumber. Berikut ringkasan isi materi pelatihan dan narasumbernya:

1. Pentingnya Instagram untuk Bisnis, oleh Maulidian, M.M.

Instagram merupakan sebuah aplikasi untuk berbagi foto dan video yang memungkinkan pengguna mengambil foto, mengambil video, menerapkan filter digital pada foto, dan membagikannya ke berbagai layanan jejaring sosial lainnya, termasuk di instagramnya sendiri. Kini, Instagram menjadi salah satu media sosial yang paling banyak diminati oleh masyarakat Indonesia dan dunia. Berdasarkan Katadata (2018) total pengguna Instagram di dunia mencapai angka 800 juta pada Januari 2018. Bahkan, berdasarkan data dari Statista (2018), pengguna aktif Instagram per Juni 2018 mencapai 1 milliar.

Berbagai tujuan masyarakat menggunakan Instagram. Selain berbagi konten visual, insagram juga saat ini banyak dipakai untuk keperluan bisnis. Ada beberapa alasan, kenapa Instagram sangat baik untuk bisnis.

Pertama, Instagram sebagai sarana terbaik untuk bercerita melalui konten visual. Dari sudut pandang bisnis, memberikan cerita yang menarik melalui konten visual di Instagram dapat membangun ikatan emosi yang kuat antara brand dan pelanggan. Kedua, salah satu strategi pemasaran yang penting adalah membagikan konten visual. Konten visual bagian utama dari penggunaan Instagram. Konten visual lebih disenangi $\quad 91 \% \quad$ konsumen dibandingkan dari pada teks (Dayan, 2018). Ketiga, Instagram dapat menjangkau banyak orang. Jumlah pengguna yang mencapai 1 milliar, akan menjadi peluang yang sangat baik untuk bisnis yang akan dijalankan.

Keempat, Instagram sebagai sarana yang baik untuk membangun ikatan emosial dengan komunitas pelanggan. Media sosial memiliki banyak fitur yang bermanfaat untuk membangun ikatan emosional pada kolom feed dan story. Kelima, Instagram bermanfaat untuk mengetahui informasi dari pelanggan dan calon pelanggan. Informasi dapat berupa feedback mengenai produk yang digunakan pelanggan maupun informasi mengenai keluhankeluhan, masalah-masalah dan harapan-harapan yang orang katakan di Instagram. Keenam, Instagram dapat digunakan untuk mengamati pergerakan pesaing dari bisnis kita. Konten-konten yang diposting pesaing dapat diamati seperti apa kontennya, kapan membagikan kontennya, seberapa sering, bagaimana konten pesaing dalam membangun hubungan dengan pelangan, dan konten lainnya yang 
Available online at https://jurnal.stmikroyal.ac.id/index.php/jurdimas

terkait dengan pesaing bisnis kita.

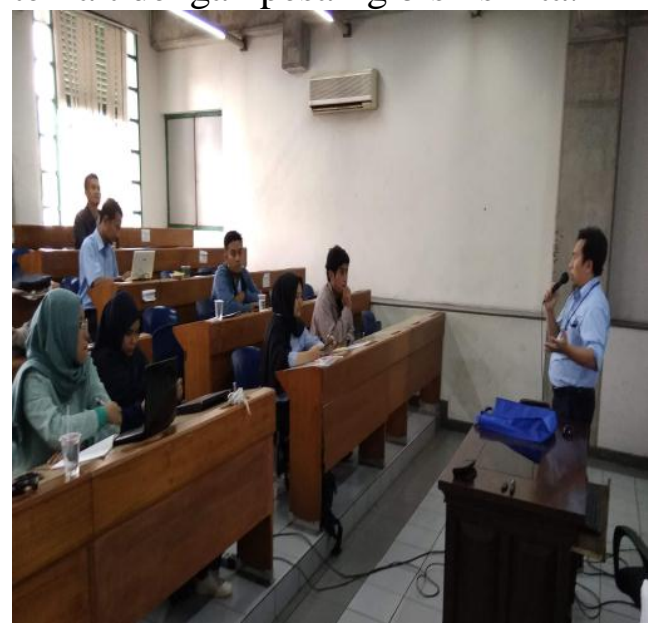

Gambar 2. Foto Narasumber ke-1 Menyampaikan Presentasi (Dok. Lahandi)

2. Mencari Foto dan Video Berkualitas untuk Konten Instagram, oleh M. Lahandi Baskoro, M.Sn.

Instagram adalah jejaring sosial yang sangat menekankan konten visual baik gambar statis (foto, ilustrasi, dsb) dan gambar bergerak (video, motion graphic, dsb). Untuk bisnis pemula kemungkinan muncul pertanyaan: Bagaimana cara mencari materi gambar yang berkualitas dan bisa bebas dipergunakan untuk promosi produk komersil, namun tidak bermasalah secara hukum?

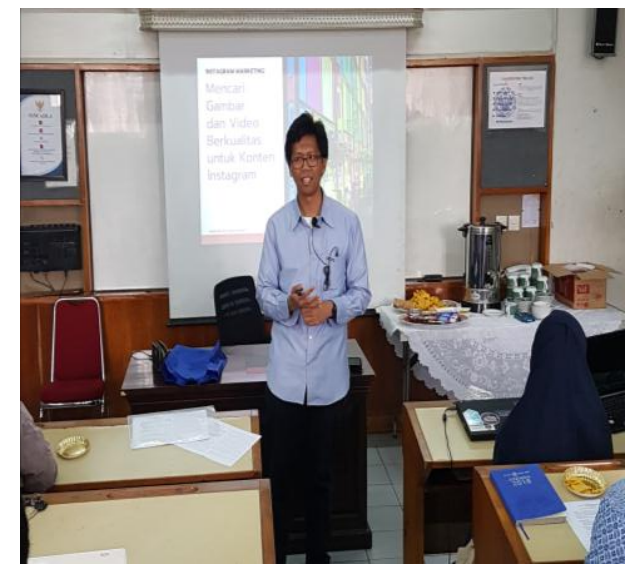

Gambar 3. Foto Narasumber ke-2 Memberikan Presentasi (Sumber: Dok. Maulidian)
Ada 4 (empat) pendekatan yang bisa dijalankan. (1) Mencari Gambar di Situs Koleksi Foto. Ada beberapa yang menyediakan secara gratis, beberapa diantaranya: Unsplash.com, Pixabay.com, Pexels.com, pxhere.com. (2) Mencari Gambar di Mesin Pencari. Baik Google ataupun Bing bisa digunakan untuk mencari gambar dengan ukuran besar dan boleh dipergunakan untuk kepentingan komersil, semuanya bisa dilakukan dengan sedikit pengaturan saat melakukan pencarian. Mencari Video di Situs Koleksi Video. Beberapa situs yang menyediakan video stock footage yang bagus dan gratis adalah sebagai berikut: videvo.net, videezy.com, videos.pexels.com. (4) Mencari Video di Youtube. Lakukan pencarian di Youtube dangan kata kunci "free video footage", nanti akan muncul banyak channel dan video yang selaras dengan hal tersebut. Kita tinggal pilih sesuai kebutuhan kita, namun biasanya untuk mengunduh dibutuhkan layanan pengunduh video entah sifatnya plug-in peramban ataupun melalui situs lain.

Kesemua pendekatan tersebut tetap perlu melihat detail ijin penggunaannya, apakah membutuhkan attribution (pencantuman nama pembuat atau pemilik) atau tidak. Biasanya keterangan ini tampil dengan jelas pada halaman foto atau video yang kita temukan melalui pendekatan diatas.

3. Mencari Produk dan Menjualnya di Instagram, oleh Eko Mujiono, S.Si.

Cara Mencari Produk. Dropship adalah sistem penjualan barang dari 
Jurdimas (Jurnal Pengabdian Kepada Masyarakat) Royal

Vol. II No. 1, Jan 2019, hlm. 19 - 26

ISSN 2614-7912 (Print)

DOI: https://doi.org/10.33330/jurdimas.v2i1.101

ISSN 2622-3813 (Online)

Available online at https://jurnal.stmikroyal.ac.id/index.php/jurdimas

suplier ke pembeli tanpa anda harus memiliki dana besar untuk menyetok barang. Keunggulan dropship: tanpa modal, tanpa perlu stok barang, tanpa repot pengiriman. Untuk melakukan dropship sebaiknya riset terhadap produk yang diminati pasar (via marketplace), lakukan juga riset supplier yang terpercaya.

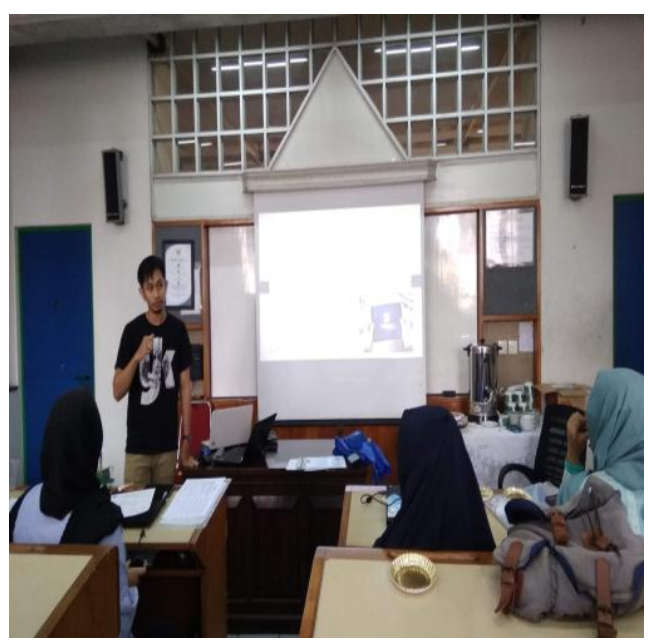

Gambar 4. Foto Narasumber ke-3

Menyampaikan Presentasi (Sumber:

Dok. Lahandi)

Instagram Marketing. Kunci utamanya adalah mendorong traffic (kunjungan) yang tinggi ke akun atau post kita, lalu konversikan menjadi sales (penjualan). Untuk terlihat meyakinkan maka perlu melakukan pengaturan dan melengkapi profil Instagram kita. Untuk strategi hashtag tipsnya adalah: hashtag harus sesuai dengan postingan, jangan terlalu banyak hashtag, bisa menggunakan aplikasi atau situs penelusur hashtag seperti Webstagram. Untuk konten, tipsnya adalah: gunakan foto yang beresolusi tinggi, lakukan posting secara konsisten dan menggunakan hashtag. Jika memiliki anggaran promosi bisa menggunakan bantuan promosi dari: akun buzzer, endorsement melalui selebgram, dan Instagram ads.

Di sesi ini diingatkan juga bahwa untuk yang beragama Islam, ada beberapa pandangan ulama mengenai sistem dropship dan juga hukum membeli follower Instagram. Hal-hal tersebut bisa dipelajari lebih lanjut sendiri.

\section{Evaluasi Kegiatan}

Acara pelatihan secara umum berlangsung dengan baik. Acara dihadiri oleh 18 orang, hal ini tercatat pada daftar hadir yang diedarkan selama acara berlangsung. Poin evaluasi yang kami rasa penting untuk disampaikan untuk menjadi perbaikan ada 3 (tiga), yaitu: (1) Ketepatan waktu. Pelatihan dimulai mundur sekitar setengah jam dari seharusnya, ini dikarenakan menunggu peserta agar hadir di ruangan terlebih dahulu. (2) Perlengkapan teknis. Tidak adanya konverter VGA ke HDMI membuat demonstrasi yang menampilkan layar handphone narasumber jadi kurang maksimal. (3) Durasi pelatihan. Total waktu efektif pelatihan yang sekitar 90 menit dirasa agak terburu-buru untuk penyampaian 3 materi dan sesi prakteknya.

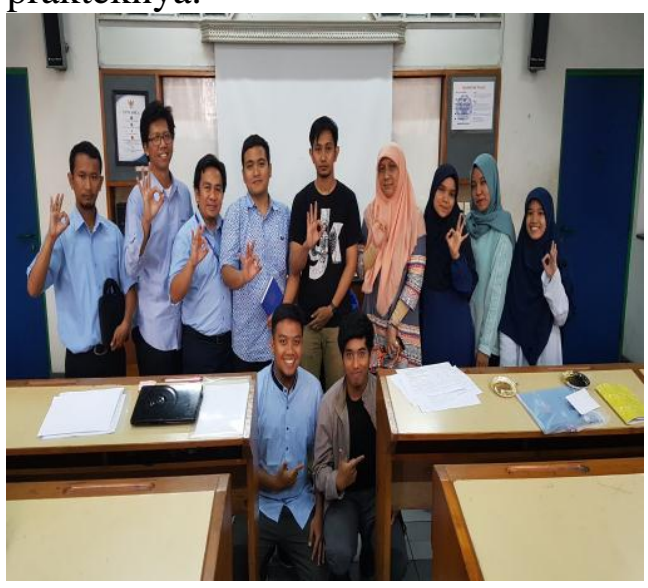

Gambar 5. Foto Bersama Seusai Pelatihan (Sumber: Dok. Maulidian) 
Jurdimas (Jurnal Pengabdian Kepada Masyarakat) Royal

Vol. II No. 1, Jan 2019, hlm. 19 - 26

ISSN 2614-7912 (Print)

DOI: https://doi.org/10.33330/jurdimas.v2i1.101

ISSN 2622-3813 (Online)

Available online at https://jurnal.stmikroyal.ac.id/index.php/jurdimas

\section{SIMPULAN}

Seiring dengan makin banyaknya pengguna aktif Instagram di Indonesia, pengetahuan dan keterampilan berpromosi melalui Instagram menjadi hal yang esensial untuk dikuasai para pemasar dan pelaku bisnis. Instagram adalah media sosial yang sangat visual, oleh karenanya penting untuk bisa memajang foto ataupun video berkualitas bagus agar bisa direspon positif oleh followers. Konten perlu di posting secara konsisten dan menggunakan hashtag yang sesuai. Jika memiliki anggaran, cara promosi berbayar bisa memanfaatkan akun buzzer, menggunakan endorsement selebgram, dan juga beriklan melalui Instagram ads.

\section{TERIMA KASIH}

Penulis mengucapkan terimakasih kepada Universitas Trilogi atas dukungan finansial yang diberikan melalui skema hibah internal Pengabdian Masyarakat sehingga kegiatan pelatihan Instagram Marketing ini bisa dipersiapkan, diselenggarakan serta dipublikasikan laporannya.

\section{DAFTAR PUSTAKA}

Asosiasi Penyelenggara Jasa Internet Indonesia. 2018. Internet Penetration and Behaviour Survey 2018. APJII

Alicia Collins. n.d. Instagram Marketing. Hubspot. Pranala: https://www.hubspot.com/ins tagram-marketing
Buffer. n.d. Instagram Marketing. Buffer. Pranala: https://buffer.com/instagrammarketing

Francesca Street. 2017. The world's most popular locations on Instagram Stories. CNN. Pranala: https://edition.cnn.com/travel /article/instagram-storiesmost-tagged-cities/index.html Instagram. n.d. Bangun Bisnis Anda $d i$ Instagram. https://business.instagram.co $\mathrm{m} /$ advertising/

Kata Data. 2018. Berapa Pengguna Instagram dari Indonesia? Kata Data. Pranala: https://databoks.katadata.co.i d/datapublish/2018/02/09/ber apa-pengguna-instagramdari-indonesia

Statista. 2018. Instagram: number of monthly active users 20132018.

https://www.statista.com/stati stics/253577/number-ofmonthly-active-instagramusers/

Sarah Dawley. 2018. How to Use Instagram for Business: A Complete Guide for Marketers. Hootsuite. Pranala: https://blog.hootsuite.com/ho w-to-use-instagram-forbusiness/

We Are Social. 2018. 2018 Digital Yearbook: Headline Internet, Social Media, and Mobile Use Data for Every Country in The World. We Are Social

Zohar Dayan. 2018. Visual Content: The Future Of Storytelling. Forbes. https://www.forbes.com/sites/ 
Jurdimas (Jurnal Pengabdian Kepada Masyarakat) Royal

Vol. II No. 1, Jan 2019, hlm. 19 - 26

ISSN 2614-7912 (Print)

DOI: https://doi.org/10.33330/jurdimas.v2i1.101

ISSN 2622-3813 (Online)

Available online at https://jurnal.stmikroyal.ac.id/index.php/jurdimas

forbestechcouncil/2018/04/02

/visual-content-the-future-of-

storytelling/\#678344923a4 